\title{
Trapped in the Digital Divide? Old People in the Information Society
}

\author{
Birgit Jæger
}

\begin{abstract}
Senior citizens have not been amongst the first to start utilising Information and Communication Technology (ICT). Thus there is a danger that they will be excluded from the growing Information Society. In a Danish program, six local experiments are trying out the possibilities of utilising ICT to fulfil the needs of old people. This article will present some of the results of the program. First, I will present the Danish ICT-policy, which shapes the political background for the program. Second, I will present the program. Third, I will give a brief presentation of the methodology and the theoretical framework the study is based on. Through an analysis of two of the local experiments I will show how ICT becomes a part of old people's everyday life. Finally, I will conclude as to whether or not old people in Denmark are becoming part of the Information Society through these local development projects.
\end{abstract}

Key words: social experiment, information society, digital divide.

For several years, it has been the Danish government's political objective to prevent the growth of a digital divide amongst the Danish population. In the late 1990s, the elderly were singled out as being a part of the population that was in danger of being left out of the Information Society ${ }^{1}$. Statistics gathered over the last couple of years have shown that the digital divide has been changing. No longer is it just the young, well-educated, wealthy men that are familiar with ICT and regular users of the Internet, now women, the lower educated and lower paid people are becoming users. The only group which is significantly behind in the use of Internet is the elderly. Thus, in 1999, the Danish Government introduced a combined research and development program called "Old People's Use of ICT".

Within this program, six locally based development projects are undertaking social experiments with different ways of old people's utilisation of ICT. One of the research projects, also funded by the program, follows these six local development projects and does research on the impacts of them. This article is based on the results of this study.

In this article, I will give an answer to the question of whether or not the pro- 
gram has actually prevented old people from being trapped in the digital divide, or whether it has instead made them a part of the Information Society. First, I will present the Danish ICT-policy, which shapes the political background for the program. Second, I will present the program, its objectives and the projects in it. Third, I will give a brief presentation of the methodology and theoretical framework this study is based on. I have chosen two of the social experiments for a further analysis where I will demonstrate how old people experience their interaction with technology and analyse how ICT becomes a part of old people's everyday life. On the basis of this analysis, I will conclude as to whether or not old people in Denmark become part of the Information Society through these development projects.

\section{Danish ICT-Policy}

As already mentioned, the Danish ICTpolicy shapes the political background for the program "Old People's Use of ICT". In this section, I will describe the ICT-policy and the way it has developed. The analysis of Danish ICT-policy is based on a literature survey of a long series of policy papers from the Ministry of Research and Technology. (The full analysis is in Jæger, 2003: 59-82).

Until 1994, the main actors in the development of the Information Society in Denmark were big national companies such as the former national PTT (Post, Telegraph and Telecommunications). Even though these companies were publicly owned, they were managed like private companies, which indicate that market forces were directing their development. In 1994, however, this situation changed because the Danish Government published the first Danish ICTpolicy.

It was not a co-incidence that the policy was published at that time. In 1993, the Government had for the first time in history established a Ministry for Research and Information Technology very much inspired by international developments. In 1992, the Clinton administration had launched the National Information Infrastructure (NII) initiative, which had inspired the European Union to set up a working group with the purpose of formulating the European strategy for the Information Society. The report from this working group (European Commission, 1994) was the direct inspiration for the Danish Government to set up a committee to formulate a Danish strategy for the Information Society. The work of this committee resulted in a report entitled "Info-society Year 2000" (Ministry of Research and Information Technology, 1994).

The strategy outlined in the report differs from the American and European strategies in two ways. First, the Danish strategy recommends that the public sector should be a driving force in the development of the Information Society, second the strategy should build on some special Danish values concerning openness in the administration and democracy. The strategy is described as follows:

"The strategy should be based on a Danish model involving that market forces are not allowed to be left alone. We must make sure that a number of special values prevail, primarily through a public sector effort:

- IT should support free access to in- 
formation and exchange of information.

- IT should support democracy and give the individual the opportunity to exercise his influence.

- IT should support personal development, one of the means being to support the individual in his working situation and in his leisure time.

- IT should support openness in the public sector, making it more transparent, contributing to the promotion of efficiency and rationalisation in public institutions and enabling them to provide better service.

- IT should be used to sustain the disadvantaged of society." (Ministry of Research and Information Technology, 1995: 12-13)

The report stressed that the special Danish values also include a societal responsibility for the weak groups in society and a political demand for making sure that these weak groups will also have access to the Information Society. This is expressed as follows: "A social responsibility for ensuring that everyone can be involved, so that the info-society really is open to all." (Ministry of Research and Information Technology, 1996: 7). In other words, the Danish strategy emphasises the importance of avoiding a digital divide.

The report placed ICT-policy on the political agenda. For the first time, ICT was treated as a political theme which had significant influence on societal development. The report almost became a best seller and it initiated a very broad discussion on technology in society. Several questions were brought to the fore in the public debate such as: Is it possi- ble to prevent a digital divide? Can it be prevented by creating universal access to technology? Will the Information Society turn out to be a surveillance society?

During 1995, the Ministry of Research and Information Technology followed up the report by making a very concrete action plan, which dealt with issues involving every area of society. The private sector was encouraged to take the same steps as the public sector and integrate technologies, such as e-mail and EDI in the companies and to develop networks between companies. Beside this, the first steps were taken towards a liberalisation of the telecom services. The first action plan has been followed up every year since then. In the following years, the action plans created many ICT related activities at all levels of society. Some of these activities were directly focused on different ways to prevent the rise of a digital divide. One of these activities is the special program “Old People's Use of ICT".

This was the dominant Danish ICTpolicy until the end of 2001. There were some minor changes in the action plans. For example, there was a shift from the first report where every ICT initiative was regarded as positive. At that time, there was an enthusiasm connected to ICT and the strategy was "let 1000 flowers bloom!" Over the years this initial enthusiasm became more realistic and a need for focusing the large number of initiatives and shape a common electronic infrastructure in the public administration was expressed. The overall Danish ICT-policy, however, has remained the same.

At the end of 2001, a new government took over. The former government was 
a coalition between the Social Democrats and the Social Liberal Party, but the new government was a Liberal - Conservative coalition. The new government published their ICT-policy in a report called "IT for all - The Future of Denmark". Here the inspiration from the EU is visible even in the title. In 1999, the EU had launched an action plan called " $e$ Europe: An Information Society for All". (The European strategy is further described in Sancho, 2002). Many of the ingredients in the Danish plan are the same as in the former ICT-policy but the weight of the different elements has changed. The public administration is still regarded as an actor in the development of the Information Society, but the driving force from then on was to be the private sector.

"The development of ICT and Telecommunications in Denmark must primarily be based on private initiative and on market conditions. The Government will primarily stimulate development by reducing obstacles and encourage a binding co-operation between public and private actors. In a few strategic areas it may be necessary that the public sector acts as a locomotive of development." (Ministry of Science, Technology and Development, 2002: 9)

The strategy also stresses that the Danes must be qualified for the Information Society, not for their own sake, but because the private companies have a need for skilled employees. The report points to the need of not just being good at utilising ICT, but also of being able to make money from it. It says:

"Denmark is a world class country of ICT-users, but we can be better in getting something reasonable out of it and make money out of it. In other words there is room for improvements. Thus the Danish ICT-policy must be more nuanced, profitable and sober than it used to be. We will reduce the clichés and focus on concrete initiatives." (Ministry of Science, Technology and Development, 2002: 41)

The concrete ideas for action in the report are very much in line with the old strategy. Actually, the former government initiated many of the activities. But as the above quotes show, there has been a shift in the overall priorities. Now the focus is on the needs of the private sector and the possibility of making money and the former talk about special Danish values, the digital divide and democracy are characterised as clichés. The new government is not worried about the digital divide, and programs like "Old People's Use of ICT" and similar programs will probably be history by now, and it is unlikely that new programs like this will be initiated by the current government.

\section{Old People's Use of ICT}

Based on this ICT-policy, the former Danish government wanted to know whether or not a digital divide based on age existed. Thus, in 1996, a committee was established with the task of making a study that mapped old people's use of ICT. The then Minister of Research and Information Technology, Jytte Hilden, explained the need for the study as follows:

\footnotetext{
"'The study is the first step in a bigger strategy and is an important sign that information technology is not only for youngsters and nerds. I believe that old people both can and will play a role in the future Information Society." (Ritzaus Bureau, 02/09/1997)
} 
The report from this study (Nielsen \& Holst, 1998) shows that old people in general are not afraid of new technology. In 1997, when the study was conducted, $19 \%$ of people over 60 years had a mobile phone, $13 \%$ used a computer in their home, but only $4 \%$ of them had tried to use the Internet. At this point, the figures show there was a clear digital divide based on age. On the basis of these figures, the committee recommended some special initiatives to prevent old people from being left out of the Information Society.

When, in 1997, the Minister of Research and Information Technology presented the annual action plan for the development of the Information Society she said to a newspaper:

\begin{abstract}
"'We are now in a new phase where we must encourage people with equipment and training in the use of information technology. I will look at the human aspects of the Information Society. The old people and the handicapped must have better access to the information technology'." (Aktuelt, 15/ 05/1997: 6)
\end{abstract}

At the same time, it became clear that demographic developments, similar to most other European countries, will result in a dramatic growth of the older part of the population in the coming years. Simultaneously, the extremely low birth rate in the 1980s will result in a decrease in the number of people engaged in active employment. Against this background, it also became a political objective to use ICT to develop services for old people - which could decrease the need for public services.

The government responded to these challenges by reserving 33 million DKr. (about 4.4 million Euros) of the state budget for a combined research and development program for Old People's Use of ICT running in 1999-2003. In this program, old people are defined as people of the age of 60 and above. It is of course a matter of discussion to define when people are old. In Denmark the official age for retiring from the labour market is 65 years, but in practice the average age for retiring is between 61 and 62 years. Due to this the government decided to define the target group for this program as all people with the age of 60 and above.

Despite this clear definition of old people the program did not operate with a clear definition of ICT. Depending on the perspective, ICT can be defined in several ways and the borderline between ICT and other technologies can be drawn at different places. Seen from a technical point of view it is possible to talk about several technologies with different definitions and technical standards but viewed with the eyes of the user it is not necessary to know about these different technical standards. This program has operated with the view of the user and has in practice worked with ICT as a notion for computers with software programmes, browsers, and connection to the Internet (without any distinction between different programmes, browsers, and ways to connect). Even though mobile phones could be included in this broad definition of ICT this (and/ ther adjoining) technology was not included in the program. The program's objectives were described as follows.

\footnotetext{
"The potential for a more flexible withdrawal from the labour market by means of ICT. The possibilities for new applications of ICT that directly aim to improve the quality of old people's
} 
lives. The possibilities for developing pedagogical methods for old people so as to build up ICT competencies among old people." (Ministry of Research and Information Technology, 1999)

Out of 70 applications, 11 projects were selected and funded. As already mentioned, six of them were locally based development projects (or social experiments). $\mathrm{O} \pm$ e to the broad scope of the program, these six projects focus on very different aspects of ICT for old people. One of the other projects was a dissemination project, which resulted in $10 \mathrm{TV}$ programs dealing with different aspects of old people's use of ICT. The final four projects were research projects. They cover different aspects including research into how old people's muscles deal with the use of a computer mouse (Jensen et al., 2002), research on the implications of ICT on the everyday life of old people (Calberg et al., 2002), as well as research on how disabled old people can utilize ICT by means of special equipment (Hansen et al., 2002), in addition to the study that follows the six development projects (Sterlie, 2004).

After a brief presentation of the methodology and the theoretical approach for the study of the six development projects, I will present two of the locally based development projects and analyse whether or not they contribute to paving the way for old people to take part in the Information Society.

\section{Theoretical Framework and Methodology}

The key factors in this program were the Senior Citizens, who were expected to build up ICT competencies through their participation in the development projects, and the technology, which should be turned into new applications based on the needs of the elders. I have chosen to base the study of the six development projects on a constructivist approach to technology. According to this approach, technology is understood as a socio-technical ensemble - or network - consisting of a variety of both human and non-human actors linked together in a network in which the technology is coming into being (Bijker, 1995; Jæger, forthcoming; Latour, 1987; Williams et al., forthcoming) .

Every human being is a part of many different socio-technical networks. To be included in a socio-technical network requires a process of socialization where the person integrate the technology in question in his or her everyday life and by doing this learns how the relations in the network are constructed. This process of socialization can be described in several ways. Bijker has developed the concept of inclusion (Bijker, 1995: 139143) to describe the degree to which the actor is included in a socio-technical network. When an actor is fully included in the network she thinks and acts completely in line with the interpretation of the technology constructed in the network. In this way, the network works as a structure for the way the person acts. If an actor is only loosely included in the network, the structuring function of the network will be rather limited.

Silverstone \& Hirsch (1992) have developed the concept of domestication to describe how people domesticate the technology and through processes of appropriation, objectification, incorporation and conversion turns the technology into a part of their everyday life. 
The process of domesticating a technology consists of both practical dimensions (like buying the equipment, installing it, placing it in the house, and using it), symbolic dimensions (like shaping a relation between the interpretation of the technology and the identity of the user, where the technology ends up being a symbol of the way of living for the user) and cognitive dimensions (in which the user learns how to use it and build up a knowledge about it). (See also Lie \& Sørensen, 1996)

Based on theories of situated learning (Lave \& Wenger, 1991) and learning in social practices (Jørgensen et al., 2002) the cognitive dimension of the process of socializing or domesticating the technology can also be understood as a learning process (Jæger, forthcoming). In this learning process the single user learns how to use the technology and by incorporating the technology in the everyday life the user becomes socialized into the socio-technical network of the technology in question.

When the socio-technical network is enlarged, for example by including new groups of users (e.g. old people) this change of the network also has an impact on the artefacts in the network (here ICT). In other words, when old people start to utilize ICT this new group of users influence the shaping of the technology. They may start to use it for other purposes than the other user groups (see Oudshoorn \& Pinch, 2003). Or they may have other needs than former users. If these new ways to interpret or use ICT are picked up by the designers (or the old people start to act as designers themselves) this situation can lead to the development of new applications of ICT, and in this way the users becomes a part of the construction of the technology.

This theoretical framework is used for the study of the program "Old People's Use of ICT". In accordance with this theoretical framework I understand the development projects in the program "Old People's use of ICT" as situations where old people can meet ICT, and by means of a process of domestication and learning be socialized into the sociotechnical network of ICT. Because ICT is in many ways already constructed by others (the hardware and software are standard products), it forms a structure for how the old people in the projects can utilise it. But the content and the way to apply the technology is not fixed and in that way the old people play a role in the process of shaping ICT.

Before we turn to the empirical study of the development project I will briefly describe the applied methodology. The study is based on six case studies each relating to one of the social experiments. The methods used for these case studies are primarily qualitative and several interviews were made with different participants in the projects. The project managers were interviewed three times during the project, in the beginning, halfway through, and at the end of the project. Depending on the aims of the individual project, different participants were interviewed while the project was running. Some of these interviews were made as group interviews others, individually. Altogether 43 interviews were conducted. The number of interviewees is far bigger than this due to the many group interviews.

Beside these interviews, there has been a close connection between the local development projects and the research project through meetings every 
half-year. In these meetings, the projects have presented the latest developments in the project, the problems they had encountered and the solutions they had found.

The case studies are also based on several written sources relating to the projects. In this way, the applications, the yearly reports to the research council, and the projects web sites are gathered as a part of the case studies. Finally, the whole program was evaluated halfway through the period. The evaluation report is also a part of the material in this study.

\section{The Active Senior Project}

The Active Senior Project is based in an activity day centre for self-reliant old people called Rosengårdcentret. All activities in the centre are organised by the users themselves. In April 2000, there were 84 activities going on in the centre, each attended by between two and 100 users. Volunteers among the users run all the activities. As a visitor to the centre one is met with a spirit of activity, energy, and a principle of old people helping each other. The centre is often used as a model for other activity day centres for old people, not only in their own local community but also in the rest of the country. (See also Sterlie, 2004).

The project was initiated by three of the users of the centre. They got grants from the program "Old People's Use of ICT" and the project started at the end of 1999. The main objective of the project was to introduce ICT to the users of the centre and by doing so improve the quality of life and make the old people more self-reliant in accordance with the basic principles of the centre.
Six workstations were set up in the centre forming an ICT-café. In this café, courses for both in-experienced and experienced users are now running. Volunteers who are old people with computer skills run the courses. They have developed a special teaching instruction and a training program based on the needs of the (old) participants. When the café is not used for training, it is open for the users in the centre. When the project started, the initiators asked for participants. 150 people immediately signed on. This was far too many, so they had to make a waiting list. Today, four years later, there are still people on the waiting list. Now they are waiting for a course for experienced users.

According to the project's own information, 584 participants have followed ICT-courses from the start of the project in 1999 to the end of 2003. This figure is not the number of persons. Some of them have followed two or three courses thus they are counted two or three times. Due to the long waiting list, the project is cooperating with other training centres in the town, which set up ICTcourses directed towards old people. Thus the total number of old people who have been introduced to ICT through the project is bigger than the number of participants in the project's own courses.

The old people in the project are using ICT for many purposes. Many of them are now writing their memories, as though they are making a genealogy. They are very busy sending e-mails to children and grandchildren. Some of them now have their private account on the computer and use e-bank services, they search for information from the local authorities and other places, they edit electronic photos and some of them 
design web sites for local associations they are members of.

Not only have the participants of the courses learned how to use ICT, the internal administration of all the activities in the centre is now run on the computers. With approximately 1,000 users of the centre and 84 running activities, it is a large business to administer. Beside this there is an administration of single standing events like theatre visits, trips to museums or picnics. Before the start of the project, all this administration was done by hand. During the running of the project, it came to serve as a department of development and turned all the administration into computerised processes. This has rationalized the administration and been a great help for the centre (Sterlie, 2004).

A web site with information about the project (www.aktivsenior.dk) is also a part of the project. All the projects funded by the program were asked to make a web site. In the beginning, it only contained information about the project, but now it is developed with all kinds of information relevant for old people. In this way, the project at Rosengårdcentret was inspired by the other projects in the program to see the possibilities of a local web site for old people.

In the interviews we asked how the interviewees understand the impact of the project. One of the volunteer teachers explained the outcome as follows:

\footnotetext{
"We produce a general understanding of the meaning of technology in society and the use of technology among old people. That is actually what we are doing. Beside that, we also decrease the technological gap between the rising generation and the old people. Because many of our participants say that 'we
}

feel inferior and stupid in relation not only to our children, but also our grandchildren because they do not understand that we are not able to do these things'.

In this way he describes the impacts of the project on a general level, but the project has also had an impact at the personal level for many of the participants. One of the participants describes the impacts of the project on his own life as follows:

"I have always hated to write and in
school writing Danish essays was the
worst. Then I ended up as the editor of
our patient's association's paper. I write
e-mails in large numbers, and make re-
plies on our debate site and so forth.
But that is only because I can do it on
my PC, otherwise I would never have...

Interviewer: What does the PC mean to you?

Everything... Yes, I can edit it, and I don't sit here and drop my ballpoint pen out of my fingers."

One of the teachers also describes how the computer can help the old people whose hands shake a little. The shaking makes it very difficult for them to write with a ballpoint pen. People who find it difficult to spell can also benefit from the use of the computer. The automatic spell check helps them to write the text. Of course, this is not restricted to old people. The impact on the individual level also results in increased self-confidence for the participants. One of the project managers describes the outcome as follows:

"It is fun to watch how people come here and want to try it. How they come the first time - very doubtful - but when they have been here a couple of times 
they just do it! It is a really nice feeling... that you can see on people that they feel that this has been a victory to start on... That self-confidence they have when they have finished a course that is very nice to watch."

In an interview with two of the project managers they describe the impact of the project like this:

"Actually, we have learned a lot I think. We have learned that old people are not as afraid of ICT as they maybe thought when they started. They are shy if they have to join a course with youngsters. But when they are put together in groups here they are much freer and are actually able to work very independently with the stuff. We have learned much about how to teach. And we ourselves have learned much about ICT.... The myth that old people should be afraid of ICT has no foundation in reality, I think."

As these quotes indicate, the impacts of the project are significant both on the individual level and on the general level. On the general level, the project has generated knowledge about old people's needs in the Information Society and that the myth about old people's fear of ICT does not hold in real life. At the individual level, several old people have been introduced to the technology, and due to this introduction they are becoming included in the socio-technical network of ICT. They go through a process of learning where they realise what ICT can - and cannot - be used for, and in this way they discover the meaning and interpretation of the technology, which is located in the socio-technical network. Described with other words they have gone through a process of domesticating the technology and incorporated it into their everyday life. By doing this ICT has become a part of their iden- tity in a way that they identify themselves as users of ICT (for a further analysis of this process see Jæger, forthcoming).

Being a member of this socio-technical network makes them experience what it is like to be a member of the Information Society. In this way, the general picture of the Active Senior Project in the Rosengårdcentre is that it has succeeded in paving the way to the Information Society for the old people and hereby fulfilled the political goal to avoid a digital divide based on age.

Of course there have also been a lot of problems during the project. One of the limits in the project is that this offer is not available to all old people. For example, the old people who are not mobile, because they are disabled or just do not walk very well, are not able to attend the centre and thus they will not have the opportunity to be introduced to the Information Society through a project like this.

The project has also revealed that senile old people are not able to learn how to use the computer. There have been several examples of participants who are beginning to be senile, who are not yet aware that they do not remember so well, who have started on the courses. But the teachers have realised that it is impossible to teach them to use the computer, because 10 minutes after they are instructed they have forgotten the instruction. Consequently it is not possible to include them in the socio-technical network of the technology.

Nevertheless, these limits do not change the overall impression of a project, which is actually making a difference in opening the door for the Information Society for a large group of old 
people and in this way decrease the digital divide.

\section{ICT-Network for Elderly Councils}

The second project under the program "Old People's Use of ICT" which will be briefly analysed here is the project ICTNetwork for Elderly Councils. This project is very different from the project at the Rosengårdcentret; it has completely different objectives and another background. To understand the project, it is necessary to start with a short description of the background.

Since 1997, there has been a law in Denmark stating that every municipality in the country has to establish an Elderly Council. In accordance with the law, the local authorities have to establish an Elderly Council to advise the local authorities on all questions that matter for old people. In this way, the local authorities are obliged to hear the Elderly Council before it makes decisions that can influence the everyday life of old people. The local authorities are also responsible for covering the costs of the council's activities. In this way, the local authorities are supposed to provide a meeting room and help the administration if the council requires it.

The members of the Elderly Councils are elected by direct elections of citizens over the age of 60 . In this way, the Elderly Councils are different from many other types of council. In most other councils, the members are appointed directly, usually because they represent a given organisation or because they have a special expertise. According to the law, the Elderly Council is obliged to represent every old aged citizen in his or her local community.
In the project "ICT-Network for Elderly Councils", twelve Elderly Councils from remote areas in Denmark are working together with the overall objective of gaining increased political influence by utilising ICT and the Internet. The idea is that the project will strengthen the cooperation between the Elderly Councils by creating an electronic network. Beside this, there are some more specific goals which are:

A common web site including relevant information for Elderly Councils has to be designed, twelve different local web sites - one for each of the participating councils - are to be constructed, the members of the Elderly Councils have to learn how to use ICT. This should enable them to use the technology in their daily work in the council, they also have to learn how to keep their local web site up to date, the local web sites can be used for communication between the Elderly Council and the old people in the local community, and in the long run, all Elderly Councils in Denmark will have the possibility to join the network (Jæger, 2004).

The case study of the project has revealed that even though it is some years ago the law about Elderly Councils was passed by Parliament, there is still a great deal of uncertainty about how the cooperation with the local authority is to be carried out. The study has shown that there are big differences in how the cooperation is working. In three selected local communities' chosen among the participating Elderly Councils, three different interpretations of the co-operation were discovered.

In the first municipality, co-operation was working very well. There were regular meetings, and the Elderly Council 
had its own budget. On the question of whether or not the Elderly Council is heard before a decision is made by the local authority, a civil servant answered:

\begin{abstract}
"Yes of course, what should I otherwise use it for. It is a channel of expression for the old people. In that way it is reasonable to do like this, because the law says that the Elderly Council has a right to have a say before a decision is made by the local authority."
\end{abstract}

The Elderly Council in this municipality also describes the co-operation as being very good. They have a room for themselves in an activity centre where the ICT equipment from the project is placed together with three other computers. Together these computers make an ICTcafé for the old people in the community.

In the second municipality, the cooperation was good but not as developed as in the first mentioned. Here also, there were regularly meetings and the Elderly Council has its own meeting room, and budget to administrate. But the civil servant thinks the local politicians forget to draw in the Elderly Council in the political process. The elderly council is first informed when the decisions are already made. The Elderly Council in this municipality is happy they have their own budget, but they also describe the co-operation with the local authority as being very slow.

In the third municipality, co-operation was poor. The meetings were not regular, the Elderly Council did not have its own budget and before the project started they did not have a meeting room. When the project started, they insisted on having a room where they could install the equipment for the project. After a conflict, the local author- ity offered them a very small room (compared to a broom closet), not big enough to have a meeting but big enough to have the equipment. The civil servant described the co-operation as follows:

"Of course we use the Elderly Council, as far as we remember to. I must admit that in general we forget to hear them. It is not because of bad will - but I am so busy. I also think it is a problem: When are we going to inform the Elderly Council? When do they have a right to have a say? Are they going to know the cases before the politicians? Or should the politicians - and they should in my opinion - have an opportunity to go into the case before you start debating with the Elderly Council and everybody else, which sometimes creates a delay.

Interviewer: But aren't there clear rules about that?

No, there aren't."

The chairperson of the Elderly Council in this municipality describes the cooperation as being filled with problems. In connection with the visions for future work she says that there are several old people who have asked her whether or not the Elderly Council could help them gain access to the technology. Thus, she would like to establish an ICT-café like the one they have in the other community. She hopes the local authority will offer a bigger room and maybe some old computers, which are going to be replaced. However, she has not asked the civil servants yet, and she fears that it will be a negative answer because both he and the politician in question have a negative attitude to the project and to ICT in general.

If the project is going to fulfil its objective, it is not only the members of the 
Elderly Councils who have to learn how to use the technology. Also the local authorities have to be able to communicate electronically if it is going to succeed. This is not the case today. In most cases, the local authorities publish the agendas and summaries of its meetings on its web site. However, all the material beside the agenda: material of the records, reports, documents from other authorities and so forth is not accessible in digital form. Thus, the local authority is not capable of communicating electronically with the Elderly Council.

The uncertainty about the role of the Elderly Council has also become visible in the process of designing the project's web sites. The project manger has travelled around to all twelve councils asking them what their need for the web site was. These questions have forced the members of the councils to make clear what their role is and what the work as a member consists of. This clarification has led to different reactions, described by the project manger as follows:

"Among the twelve Elderly Councils some of them are very clear about what their role is, but there is also somebody who is not at all clear about that. What happens when we start to ask specific questions is that they are not only uncertain about ICT but also about their work in the council. When the work is going to be put on a screen you have to know what it is. That is you can no longer be unclear and say: 'Well, we'll talk it over'. So it forces them to be concrete and make their role clear. In this way, the technology is very educative, and it starts a reflection about what they are elected for. For some of them, the result is that they do not want to run for election next time, because they have realised that this is bigger or different from what they want. For others the result is that it is getting more challenging. In this way, the project has resulted in some discussions about their role in the council."

The project has also resulted in a bigger visibility among the Elderly Councils and the local authorities. When the common web site was designed, the project manager gathered information about the conditions in the different municipalities. Because it is now possible to compare the conditions from one community to another, it becomes visible to the councils how their own conditions differ from the others. This knowledge is a very useful tool when the council is going to negotiate with the local authority. One of the members of an Elderly Council describes it as follows:

"We have probably reached a higher level, if you understand what I mean. Exactly because we are able to reach some information we are getting cleverer both at asking questions and talking for ourselves."

Based on this analysis, the conclusion is that the Elderly Councils actually have gained increased political influence, which was the goal of the project. (Jæger, 2004). The project has made it clear what the role of the Elderly Council is. This clarification is important because it has made it clear that it is not sufficient to inform the Elderly Council about a decision when the local authority has already made it; they have a right to be heard in the policy process before the decision is made. In this way, the Elderly Councils have become more visible as a part of the political process. The project has also resulted in a bigger visibility across the Elderly Councils and the local authorities. This transparency has increased their knowledge, which they 
can use as a power base in their negotiations with the local authorities. In this way, the ICT-Network has increased the political influence of the Elderly Councils and thereby fulfilled some of its objectives.

By introducing the members of the Elderly Councils to the use of ICT, it has become possible for them to use the common web site as a source of information. Their use of ICT does not stop there, however. They are also introduced to the Internet in general and there are several examples on how they use different web sites (e.g. the Parliament's) as a source of information. In this way, it is possible to conclude that the project has paved the way to the Information Society for the members of the Elderly Councils.

These are important results of the project, but the objectives of the project were broader. It was the idea that the members of the Elderly Councils should also be able to use the technology for a political debate among themselves and the old citizens they represent. This part of the objectives was not fulfilled, there were no examples of debates among the member of the councils or between the councils and the old citizens (Sterlie, 2004).

To use the electronic network as tool for political discussions is also a very challenging objective. It is a general experience that it is very difficult to realise the democratic potentials in the technology (Jæger, 2003; Olsen et al., 2004; Torpe, 2004). Thus, it would have been a remarkable result if the project "ICT-Network for Elderly Councils” had provided an example of a lively political debate. In that case the project would have served as a spear head for the rest of the society.

The empirical answer as to why this objective is not fulfilled is that the members do not yet have enough training in the use of ICT. According to the theoretical framework of the study, the explanation is that the members of the councils have not fully domesticated ICT. They do have access to the computer of the council but most of them do not have a computer in their own home. Thus they have not fully incorporated the technology in their everyday life, it is not yet a part of their daily routines, and they do not yet identify themselves as users of ICT. In this way they are not yet fully included in the socio-technical network of the technology.

It also takes some time to realise all the possible ways to utilise ICT and due to experiences from other technologies, in which the seniors are already included (for example TV and radio), it is easier to discover the possibilities to use the technology as a source of information than as a channel for political discussions. Another explanation could be that the Elderly Councils do not have the need for further political discussions. If they feel they have had the necessary discussions when they meet face to face they do not look for other channels to fulfil this need. In that case they will not interpret ICT as a tool for this purpose.

To sum up, the project has fulfilled a part of the objectives. The members of the Elderly Councils have learned how to use ICT as a source of information. In this way they have been included in the socio-technical network of ICT and they have become a part of the Information Society. At the same time they have access to information, which they can use in the political process and by this they 
have increased the political influence of the councils.

But the other part of the objective that they should use the electronically network to political discussion among the councils and between the councils and their constituencies - is not fulfilled. To fulfil this objective would require a higher degree of inclusion in the sociotechnical network. This is only possible if they domesticate ICT in a further process where they discover the potentials in the technology for a political discussion.

\section{Trapped in the Digital Divide?}

This analysis of two of the development projects in the program "Old People's Use of ICT" has been the basis for reaching some conclusions, which are closely connected to the two case studies. "The Active Senior Project" had had both general and individual impacts and had fulfilled the political goal to avoid a digital divide by including the seniors in the socio-technical network of ICT. The "ICT-Network for Elderly Councils" had included the members of the elderly councils in the socio-technical network of the technology and as a result of that the project fulfilled its own objective to increase the political influence of the councils. However, it is also possible to draw some conclusions on a more general level and answer the question introduced in the beginning of this article of whether or not old people are trapped in the digital divide.

First, the study of the two projects shows that old people are not afraid of ICT. The overwhelming intake of participants at the courses at the Rosengårdcenter, as well as in the other developmental projects, shows that old people are eager to learn about ICT. They are indeed motivated for learning how to use the technology.

The study also shows that old people are capable of learning how to use the technology. According to the theoretical framework of this study, the process of learning how to use the technology is a matter of including the user in the sociotechnical network so relations between the old and the technology are established. The participants in these projects preferred to be included in this sociotechnical network together with other old people and the instructions were given at their own speed and repeated many times (Jæger, fortcoming). These conditions were agreeable for the seniors and made it possible for them to domesticate the technology.

In particular, the project "ICT-Network for Elderly Councils" has revealed that by the use of ICT, old people get access to information, which they can use, for example, in the political process in the Elderly Councils. By getting access to information seniors have access to the Information Society.

The study also makes clear that old people find a lot of different ways to utilise ICT. In this way, it becomes visible that ICT does not have one single meaning for seniors. They interpret ICT as a tool which can be used, not surprisingly, for many different purposes - just like people of other ages do. On the other hand, this does not mean that old people interpret ICT in exactly the same way as other age groups do. Old people are often searching for information which is different from younger people's needs and interests, thus it gives meaning for them to have special web sites and other electronic services designed for their age 
group. In this way, old people become a part of the process of shaping the technology because they bring in new interpretations of how to use ICT.

The seniors also become a part of the shaping of the technology due to the fact that they have started to utilise it. By utilising ICT they force other actors to change their interpretation of the technology. Until recently, ICT was not interpreted as a tool for old people, thus developers of electronic services have not thought of them as a target group and they have not developed services for the old. The fact that seniors in these projects have shown that ICT is also a tool for this age group will probably lead to the development of new digital services targeted at old people.

The findings indicate that old people in Denmark are not trapped in a digital divide. The findings from the program are that old people are eager to learn how to use ICT, the projects have shown that it is possible for the seniors to domesticate the technology and become a part of the socio-technical network of ICT, and in this way the seniors are being included in the Information Society. The old participants in the projects have also shown that they have a lot of different purposes for their use of ICT. By using ICT for their own needs, the participants in the projects have shown that ICT is not just a tool for youngsters but also a tool for Senior Citizens.

In a few years time, the people who retire from the labour market will be a part of the Information Society already. At that time, we will probably not need programs like the Danish research and development program. Today, however, we are in a situation where a large number of the old people are not able to use the technology, and it is very unlikely that they will automatically become members of the Information Society. They need some special initiatives and some extra resources to open the door to the Information Society. Thus, it is important to establish programs like this for the time being.

The program does not prohibit every old person in Denmark from being trapped in the digital divide. As indicated in the Active Senior Project, there is still a group of old people which is not able to benefit from ICT even if it is developed amongst a network of seniors. Senile and immobile old people were not able to join the program and become part of the network. This must not, however, lead us to the conclusion that the program failed. It succeeded for a large group of old people, but it makes it clear that we have to think in other directions of activities if we want to get the groups of seniors, which were not reached by this program, into the Information Society as well.

The overall results from the Danish program "Old People's Use of ICT" show that old people can have the benefit of being a part of the Information Society and they have a role to play in this. Thus my answer to the question raised in the introduction is that old people in Denmark in general are not trapped in the digital divide - the program has had the impact of letting old people into the Information Society. Of course there is still a lot of work to do to introduce all the interested seniors to the technology, but the program has showed that it is possible to do it, and we now know how to do it. In this way, the program has served as the wanted tool for avoiding the digital divide based on age, which was the 
political objective for the program.

\section{Notes}

1 There is a theoretical discussion going on which is concerned about defining the Information Society or the Network Society (e.g. Webster, 2002). I will not go into that discussion in this article, but instead use the concept of an Information Society as a description of a society where ICT and the Internet is used as a common tool for many purposes. In this perspective, the Information Society is a place where it is necessary to have access to the technology and competence to utilise it to be a valid citizen.

\section{References}

Bijker, W.E.

1995 Of Bicycles, Bakelites, and Bulbs. Towards a Theory of Sociotechnical Change. Cambridge, Massachusetts: The MIT Press.

Carlberg, N., Søgaard, K.L. \& Østergaard, L.A. 2002 "Ung teknologi og gamle mennesker" (Young Technology and Old People). Copenhagen: Akademisk.

European Commission

1994 Europe and the Global Information Society. Recommendations to the European Council. Brussels: EU.

Hansen, K.M., Nielsen, G. \& Aalykke, S.

2002 "Ældre og IT. Håndbog til IT-undervisning af ældre med funktionsnedsættelser" (Elderly and IT. Handbook for IT-training of elderly with decrepitude). Aarhus: The Danish Centre for Assistive Technology.

Jensen, B., Laursen, B. \& Sandfeld, J.

2002 The Effect of Ageing on Performance and Muscle Activity During Computer Jæger, B. Use. BCS HCI: London.

2004 "Det grå guld søger politisk indflydelse" (The Grey Gold is Seeking Political Influence). In Hoff, J. (ed.) ”Danmark som informationssamfund" (Denmark as an Information Society). Aarhus: Aarhus Universitetsforlag.
2003 ”Kommuner på nettet. Roller i den digitale forvaltning" (Municipalities on the Net. Roles in the Digital Government). Copenhagen: Jurist- og Økonomforbundets Forlag.

Fortcoming ”Ældre tæmmer musen - og bliver aktive borgere i Informationssamfundet" (Elderly Domesticate the Mouse - and Become Active Citizens in the Information Society). Copenhagen: Samfundslitteratur.

Jørgensen, C. H., Warring, N. \& Andersen V.

2002 "Læring på arbejdspladesen - den lærende i centrum" (Training on the job - the trained at the centre). In Larsen H. H. \& Svabo C. (eds.) "Fra kursus til kompetenceudvikling på jobbet" (From Courses to Development of Compentences at the job). Copenhagen: Jurist- og Økonomforbundets Forlag.

Latour, B.

1987 Science in Action. How to Follow Scientists and Engineers Through Society. Cambridge, MA.: Harvard University Press.

Lave, J. \&Wenger, E.

1991 Situated Learning. Legitimate Peripheral Participation. Cambridge University Press

Lie, M. \& Sørensen, K. (eds.)

1996 Making Technology Our Own? Domesticating Technology into Everyday Life. Oslo: Scandinavian University Press

Ministry of Science, Technology and

Development

2002 "IT for alle-Danmarks fremtid" (IT for Everybody - The Future of Denmark). Copenhagen.

Ministry of Research and Information

Technology

1994 "Info-samfundet år 2000" (The InfoSociety Year 2000). Copenhagen.

1995 From Vision to Action. Info-Society 2000. Copenhagen.

1996 The Info-Society for All - the Danish Model. Copenhagen.

1999 "Baggrund" (Background). www.forsk.dk Nielsen, E. B. \& Holst, C.

1998 “Ældre \& IT” (Old People and IT). Copenhagen: Dansk Institut for Ældrepædagogik. 
Olsen, L., Christensen, S. \& Rieper, O.

2004 "Brug af internettet i det kommunale demokrati - Søllerød Kommune som case" (Use of the Internet in the Local Democracy - Søllerød Municipality as a case). Copenhagen: AKF Forlaget

Oudshoorn, N. \& Pinch, T. (eds.)

2003 How Users Matter. The Co-Construction of Users and Technologies. Cambridge, Mass.: The MIT Press.

Sancho, D.

2002 "European National Platforms for the Development of the Information Society”. Pp. 202-227 in Jordana, J. (ed.) Governing Telecommunications and the New Information Society in Europe. Cheltenham: Edward Elgar.

Silverstone, R. \& Hirsch, E. (eds.)

1992 Consuming Technologies. Media and Information in Domestic Spaces. London: Routledge

Sterlie, M.

2004 "Seks skabelsesberetninger" (Six Stories of Genesis). Roskilde University.

Torpe, L.

2004 "Demokrati på nettet. Status og perspektiver i danske kommuner" (Democracy on the Net. State of affairs and Perspectives in the Danish Minicipalities). In Hoff, J. (ed.) "Danmark som informationssamfund" (Denmark as an Information Society). Copenhagen: Samfundslitteratur.

Webster, F.

2002 Theories of the Information Society. 2nd Edition. London: Routledge.

Williams, R., Stewart, J. \& Slack, R.

Forthcoming. Experimenting with Information and Communication Technologies: Social Learning in Technological Innovation. London: Edward Elgar.

Birgit Jæger

Department of Social Sciences

Roskilde University, Denmark

birgit@ruc.dk 